\title{
THEORY OF IBN 'ARABĪ IN THE COSMIC SYMPTOMS
}

\author{
Salahuddin Mohd. Shamsuddin ${ }^{* a}$ \\ Mohammad Zaki Abd Rahman ${ }^{\mathrm{b}}$ \\ Mat Taib $\mathrm{Pa}^{\mathrm{b}}$ \\ ${ }^{*}$ Faculty of Arabic Language, Islamic University Sultan Sharif Ali, Brunei Darussalam \\ ${ }^{b}$ Faculty of Languages and Linguistics, University of Malaya, Kuala Lumpur, Malaysia
}

\begin{abstract}
Ibn 'Arabī believes that the cosmic symptoms or fact of the facts is one of the manifestations of the mediator between the divine and the world. Its mediation means that it represents the contents of old divine knowledge. The science is a fact in the psychology related to the nonexistent and existent. The fact of the facts or the total truth is the sum of the facts that constitute the divine science. The science belongs to both: The nonexistent and existent. Ibn 'Arabī is in the favor of idealistic philosophy of Plato: "Everything has created on the image of its essence, the essences of things are prior to their existence", i.e., it was in the divine knowledge when it was in the nothingness. Thus Ibn 'Arabī avoids the presence of any existent had its real existence before being in the divine knowledge. The total fact of the facts cannot be labeled by "the possible", as it is understood that the total fact of the facts do not accept the real existence, which can be acceptable to the possible, although it is possible for the total fact to appear in the features of real existence as it is in the reality.
\end{abstract}

Keywords: Divinity, Cosmic Symptoms, Absolute Nothingnes, Mental Existence, Fact of the facts or the objects existed in their nothingness.

${ }^{*}$ Corresponding author:

shamsuddinsalahuddin@gmail.com

eISSN 2636-9265 (C) Centre for Civilisational Dialogue 


\section{Introduction}

\section{Muḥuddī̄n Ibn 'Arabī}

Muhyuddī̄n Ibn 'Arabī is the founder of the doctrine of "Pantheism" in Islam. He believed in deanthropomorphism and analogy. He did not ignore for a while to put them both together. Ibn 'Arabī narrated the meaning of deanthropomorphism and analogy in the sense of the unlimited and limited or bounded in the same time, which means that God is unlimited absolutely and beyond every boundary or limit, and $\mathrm{He}$ is also omnipresent. $\mathrm{He}$ is similar in the sense, that $\mathrm{He}$ appears by His attributes and names in the image of every limited thing, and $\mathrm{He}$ is restricted in His appearance, as the requirements of images show that the deanthropomorphism and analogy both are two sides of the same fact, which means that they are two, only in the name. So "the infallible God and the creatures, which are similar to Him, both are one. So, there is no difference between them except one fact, which is unique to God that He must be found in His existence." [1]

Among those who have explained his book: (Fușūṣ al-Ḥikam: The lobes of wisdoms) and disseminated his beliefs and theories in the philosophical mysticism, on the top of them, were Wahīd al-Dīn al-Kirmānī, Șadr al-Dīn al-Qun̄̄, Mu'ayyid al-Dīn al-Jindī, Fakhr alDīn al-'Irāqī, Dā'ūd bin Maḥmūd al-Qaișarī, 'Abd al-Raḥmān alJāmī and others.

On the other hand, the prominent opponents included Ibn Taymiyya (deceased in 728 AH.), Ibn Khaldūn (died in 808 AH.), Ibn Hajar al- 'Asqalān̄̄ (died in 852 AH.) and Ibrāhīm al-Biqā' '̄ (deceased in 858 AH.). Al-Biqā' $\overline{1}$ had authored some books against Muhyuddīn Ibn 'Arabī, such as: (Caution of the Prophet on the infidelity of Ibn 'Arabī). Jalāl al-Dīn al-Suyūṭī had also responded to Ibrāhīm al-Biqā' $\overline{1}$ through his book entitled: (Caution of the Prophet in the acquittal of Ibn 'Arabī). [2]

Ibn 'Arabi was the first one who introduced in Islam the mystical idea of "the full human being" in the seventh century AH. The summarized line of his words was that God gathered the angels to honor Adam and asked Satan what prevented him to prostrate to Adam? Adam was the only person who had a combination of the divine picture and his human picture, which was necessary to be 
required by all of them. Satan did not have these two traits together. So Adam was caliph of God on the earth. Satan had not his image like his Creator, so he was not eligible to be His successor. Therefore, the succession was true for the full human being only. Therefore, God Almighty made his exterior image on the phenomenon of the realities of the world and his inner image on the image of Himself. [3]

Ibn 'Arabî is a connecting link to the previous philosophical mystic heritage. He made a major impact on those scholars who have come after him in the field of Islamic philosophy. The importance of the study of Ibn 'Arabī demonstrates importance of the heritage left by his predecessors, to discover the ambiguity in the concepts and perceptions, which is found among the predecessors of the Sufis, which needs the further clarification.

\section{Divinity (The Mediator)}

Before discussing the cosmic symptoms or the total truth, we should say a few words on the divinity first, as being a part of (the cosmic symptoms) or (the total truth). The imagination or the isthmus to Ibn "Arabī represents the first four mediators, namely: "The divinity", "the cosmic symptoms" or "the total truth", "the objects that are fixed into the nothingness" and "Mohammadiyah Fact".

Here we have to clarify that we will study here only the second mediator, i.e. "the cosmic symptoms" or "the total truth" in some detail.

The divinity is a mediator between the divine self and the human world. It brings both of them together, as it is a group of the divine names that are the divine actors in the affairs of the human world. By this mediator, Ibn 'Arabī attempts to solve the dilemma of bilateral between the self of God and His divine attributes, which was a basic dilemma in Islamic theology.

The divinity represents an eternal presence, which mediates between the self of God and the world, and meets both of them alone. Ibn 'Arabī says: "The divinity (the mediator) itself meets the creatures, as well as meets the divine. It means that God reflected in the images of creatures by this face, as well as it meets the divine self by the same face. The creature does not know about God, only 
behind this mediator: the isthmus or imagination. God, Himself has no control in the creation of the creature, but only behind this isthmus or imagination, which is called the divinity. We have checked, we could not find but the beautiful names of God. It means that God has no power in the world, but only through these divine names. As well as, we do not know about God, but only through these names of God. These are the features of these reflections. [4]

Such a concept of the divinity (the mediator) does not contradict with that is known as the theory of (pantheism) to Ibn 'Arabi, where he talks about a lot of styles of the expression through the metaphorical and figurative photography. If we choose one of them that is an example of the multiple mirrors that reflect the multiple images for one thing by the multiplicity of the mirrors and their different nature, we realize that this example - in its sensorial perception - demonstrates the meaning of a comprehensive existential unity to Ibn 'Arabī in a clear indication completely. This unit stands basically on the existence of some different mediators that are the multiple mirrors having their different nature - reflecting the divine, so the multiplicity of the images is because of the multiplicity of mirrors, but it does not reflect any multiplicity of the divine itself.

As long as the divine range of the proportions and additions mediate between the oneness and abundance, the divinity must have two sides, one side to the oneness and the other side to the multiplicity. Besides, the two binaries: the oneness and multitude, and bringing both of them together, as both of two binaries of being the absolute and bounded, old and modern, being and nonbeing should also be kept combined. The multiplicity of the divinity stems from its diversity of the proportions, additions and the relations that are expressed by this multiplicity. Its oneness is to indicate that the self-dispensing is related to the absolute (God) and lack of the selfautonomy is related to the bounded (the human world). This relationship is the divinity of the divine self in its unity. It is one because it indicates the probative character of the divine, which is a prescription of self-dispensing. This prescription is not related to a macroscopic existential thing, but to its mental opposite, which is indicated by the lack of the self-autonomy from the world of possibilities existed since the immemorial time in the knowledge of God. This relationship between (self-dispensing and the lack of self- 
autonomy) is the divinity, which is indicated by the name of Allah (God).

The divinity in this sense has two sides: the unity, which is shown in the name of Allah (God), the abundance, which is shown in the divine names in the rest of the universe. The relationship between the two sides is not based on the separation, as the abundance is included in the unity by force, but the both are counted as the two aspects of the same truth. First refers to the divine self from one side, and the second refers to the world from the other side. So the function of this mediator (the divinity) is a transcendence of the divine self per se from the immersion in the affairs of the world.

\section{Cosmic Symptoms or Fact of the facts or Total facts}

There are various names for these total facts used by Ibn 'Arabī. They are the "origin of the world, the origin of the individual essence, the orbit of life and the right that the creature has to be found by it". This is "the fact of the facts or cytoplasm or the first substance or the genus of the sorts" or "the initial facts or the highest genus". [5] All these names mediate between God and the human world.

This total fact -with its third place of medium existential ranking between the ubiquity and boundness (restricted) or additionlinks between the divine and the world as the mediator. Its being as a third thing is a reasonable, but it is not a perceptible object. The world appeared by this third thing, i.e., it is the total fact for every fact, which is reasonable to the mind, which appears in the ancient as the old past and the modern as a new event.

Ibn 'Arabì says: "If you say that this third thing is the world, you have a right, if you say that it is the God Almighty exalted, you have a right. Though if you say that it is not the world, neither the God Almighty exalted, but you have also a right to say that it has an additional meaning. It is true to call it by all of this, as it is the overall broader combinatory for the old and new comprehensively. It multiplies by the multiple existing creatures, but cannot be divided by the division of creatures and information. It has not existed but existed. It is the world, but not the world. It is so, but it is not so... The world itself has been non-existent. In this case, it cannot be 
described by the presence or not presence, but the old divine knowledge relates to which is contained by this third thing overall detail... No one can explain the reality of this third thing that we are talking about, but we can point out its reality by using some kinds of metaphor and presenting some examples. Thus, it is separated from the divine (God), Which does not fall under any example except as the point of His act, as He is also not the Predictor of His reality: the proportion of this thing -which cannot be limited and cannot be described by the existence nor nonexistence and not by the new nor by the old." [6]

This fact points that this reasonable mediator mediates between God and the world is not a physical mediator. It is the divinity itself or the divinity as it manifested in the character of science. The science to Ibn 'Arabī is not a recipe redundant. It is attribution, which is related to the God Himself. This fact - on the other hand - is the world; therefore, it can be described by the oldness and newness and also by the existence and nonexistence.

In the fact, the fact of all the facts, which can be described by all the conflicting qualities unites with the divinity in its collective sense, but not limited to the quality of science; as the science -as being an attribution- can be included in the fact of the facts - as being one of its realities or one of its attribution. The science -from the other side- includes the totals that contain the divinity and the world together, as well as the total fact of the facts. The relationship between the divinity and fact of the facts, and both of them and the science, on the other hand, is a relationship of matching in its reality, although, it is possible to differentiate between these levels.

Ibn 'Arabī describes drawing a table for the divine in his book: "Creation of the circles" the relationship between this table and the facts of the facts saying: "We started from this table (means the table of the presence of divine) in the creatures, because God is the first that Has not any priority to Him, where all of the things have not existed. Therefore, we draw it in the shape of a primordial substance and with Him, because it has been joining to Him in the eternity without being existed, but it is known to Him (God). God knows it by one of its realities, not without it because this fact includes everything that the (God) in the eternity was its apparent, as this fact was His soles, because it is a description of the science as a science is not something else." [7] 
The fact of the facts is equal to the divinity from the both sides: The existential side -because they both belong to the same intermediate position between the ubiquity and the added presenceand the cognitive side, in the sense that both of them represent the theme of divine knowledge and its content. So each of them necessarily- is included into the other, as each of them can be described by the same character, as both of them are, in fact, the two levels of the same fact. So there is nothing strange in the description of Ibn 'Arabì when he says that "the fact of the facts is the circle surrounding the creatures as the whole without any restriction. It contains on all of the facts known that they have their existence or not or they are nonexistent. This fact has the reasonable life, which can be described as the old in the oldness and the new in the newness. This fact also has the scientific and voluntary capacity." [8]

Then it can be said that this fact of the facts is united with the divine science, it is more comprehensive than the same recipe of the science because the science is a part of the lineage. It extends to life and will. The attachment of the divine science to its subject - which is the divine-self - is the same attachment to the fact of the facts, as to the world. [9] So there are some multiple attachments, but the thing attached is one, and there are many and many multiple attributions, but the fact is the same.

Ibn 'Arabī does not describe these facts with the existence or nonexistence, and puts them in the middle between the ubiquity and bounded and added. When he talks about the mattresses and creatures in their spiritual and physical existence, he means their abilities to accept the bias from their nonbeing and puts these facts in the fourth level. As they are the creatures that do not accept the bias alone, but by the extension, they cannot be found by themselves, but they are resolved in the others, these are like the symptom: Blackness, whiteness and the others like that, including the creatures of attributions that belong to what happens to the self that we have mentioned as the three groups of the creatures. The first is the ubiquity who cannot be realized that what He is, He is God. The second is out of the material, like spiritual minds that accept the figure and shape, namely the angels and jinn. The third is that existent, which accepts the bias and places, like the celestial objects, 
the bodies and the individual essences. They also have some other symptoms, like where, how, the time, number, quality, quantity, amount and addition, situation and to do and to get excited. Every one of these creatures is divided in itself to many things." [10]

Ibn 'Arabī considers the fact of the facts with its mediation between God and the world, between the absolute and fettered, between the biased and un-biased, i.e. between the unseen world and the real world, which is seen. So it is reasonable, which is not remarkable in itself, although it is possible to see where the things are biased. If this fact is ruling the whole presence on the base that it can be true to use for Allah (God) and the world. It means that this fact from this point of view is a process of coming out from an unseen world to a real world seen in the case that it accepts the bias in the world, but it will be back again to the unseen world, on the basis that the symptoms cannot remain two times continuously.

It means that the fact of the facts has a permanent movement between the appearance and disappearance because the world -in the eyes of Ibn 'Arabī- is not a project completed already, but it is in the case of a continual creation, which is always ongoing. Each step is a new creation, resulting from the continual divine manifestations. Therefore, Ibn 'Arabī calls the fact of the facts by the name: "The cosmic symptoms". The things that came out of the unseen world to the real world, and then moved to be unseen again are called the cosmic symptoms. Now the question is: Are they counted as the real things? Are there some conditions not characterized by the existence or nonexistence, which can be understood, as the proportions? It is one of the divine secrets. The people had been mystified by these secrets. They are not God. They do not have a real existence and can be from the world. They are some reasonable facts if you attribute them to God, there might become accepted by Him, as it is not impossible for Him to do so. If you attribute them to the world, there also become accepted by it, as it is not impossible to be attributed to it. Then it is divided into two parts in the matter of God. First, which is impossible to be attributed to God, i.e., that cannot be attributed to Him. Second, that is not impossible to be attributed to God can be acceptable by the whole world, except the unlimited ones since it would not be in tune with the world. These reasonable facts have no limit, but others have so that these facts could be attributed to God and the world; although they are not from God and also not from the 
world, they do not have their real existence, but it is impossible for the mind to deny their knowledge. So here was the confusion, big problems appeared, the people separated, and the confusions intensified. Nobody can know about it except who has been given the knowledge about it by God. That is the real unseen world, as there is nothing that can be seen and later moves towards the unseen after being seen. It is not impossible to be considered a pure nothingness. It has not a real existence to be considered that it is pure existence. It is not a possible, which has both sides equally, i.e., being and nothingness. It is not unknown, but well known reasonably. Therefore, it cannot be defined. It is not a worshiper and also not a worshiped God. So it was better to be called the unseen, not to be called the seen because it has no real existence to be seen some time. This is the real unseen world chosen by God Almighty only for Himself." [11]

\section{The link between the divinity and cosmic symptoms or fact of the facts}

The link between the fact of the facts and the absolutely unseen in one side and the link between them and the proportions on the other side asserts that the fact of the facts unites the divine names that represent the divinity as the whole. The fact of all the facts is unlimited as the whole. From this angle it unites the divinity and then it is attributed to God, as well as it is attributed to the world, and it is valid. The recipe of being limited is a quality or proportion, which is acceptable to the world, as being one fact of the facts, and it is valid, but it is not valid to be attributable to God. On the contrary, the recipe for being unlimited is not at all attributable to the world, but it is attributable to God. Apart from these two, both unlimited and limited, the world and God both participate in all other attributions contained in the fact of the facts. This perception of the fact of the facts is not far from the perception of divinity by an initial bilateral relationship, which is dispensed by the divine and the lack on the part of the world. As all the relationships and attributions or divine names, they represent relationships shared by the self, Divine and the world. 
It confirms this linkage and unification between divinity and the fact of the facts that Ibn 'Arabī conveys to the world. This statement means that it has a cognitive function in addition to its existential function. These two - the existential and cognitive functions - equally apply quite to the divine names, that are also reflected on the hearts of those who have the divine knowledge, which gives the knowledge according to the nature of the manifest name. Thus, the qualities and divine names unite existentially with the cognitive fact of the facts, because he says: "The God exemplified by the slaves on the wills of His qualities. For this reason, the people (Mu'tazilas) deny seeing God in the hereafter, because the God manifested to them in the image and quality that was completely different to that image and quality which was known to them. God will be manifested on the hearts of those who have the divine knowledge themselves in the afterlife in general. This is a side of the similarities". [12]

\section{The difference between the fact of the facts and divinity}

The difference between the fact of the facts and divinity is only a perceptual difference, not a real difference. It is the primordial substance, as "God created the upper and lower creatures from its material and it is the universal mother of all creatures". It is reasonable that the mind has not a real existence as the essence, which has a self-image, but it is amongst the creatures without the sub-divisions, increasing or decreasing. Its existence depends on the emergence of notables creatures. Its existence depends on the presence of individuals and their knowledge in detail depends on its knowledge." [13]

The fact of the facts and divinity -both together- are two essential conditions for the emergence of the world. Ibn 'Arabi considers them as a condition not as a cause, on the basis that the cause requires the effect. On the contrary, there is no parole without the presence of its reasonable condition. [14] This consideration makes Ibn 'Arabī to maintain a kind of independent existence - at least the mental existence - for each of the fact of the facts and the divinity. However, their notable sensuous appearance, i.e., the emergence of their provisions, is linked to the emergence of the world from its scientific existence to the sensuous existence. "If God 
did not enter the creatures by their pictures the world had no existence. As well as, if those total reasonable facts were not found any rule would not have appeared in the physical creatures." [15]

\section{Sources of Ibn 'Arabī in the theory of "Cosmic Symptoms."}

No doubt that Ibn 'Arabī gleaned from some Eastern and Western philosophical theories in his theory of "cosmic symptoms" as discussed below:

\section{Theory of "Part and Parcel" to Mu'tazilas}

'Abu Hudayl al- 'Allaf presented his theory of "individual essence" or "part and parcel" or atom". He sees that it consists of the total individuals by the accession to each other. The substance is the one that bears the different conditions and situations according to its amount. [16]

This theory is attributed to 'Abu Hudayl al-'Allaf, Mu 'ammar b. 'Abbad al-Sullamī and Hishām al-foṭ̂̄ from Mu'tazila of Basra [17]. His theory in "the individual essence" was accepted with great interest by the scholastic theologians generally, but the theory of "part and parcel" used by the scholastic theologians, which was crystallized by Mu'tazila had some certain reasons [18].

The theoretical basis of "the individual essence" stands on that "the part of the essence that has a special status does not accept to be divided originally, not according to the outside and not according to the delusion or mental hypotheses. The objects to Mu'tazila are composed by the integral parts. The objects consist of individuals by the accession to each other. The world is a composition of these individual essences, or the parts do not accept the partition or division [19].

'Abu Hudayl had tried to solve the problem of change and stability in the world by the theory of "individual substance", to interpret its link with the first cause, the continuously change in nature according to the laws and conditions found under its shade. 'Allaf assumed that the world is made up of these mini micro-atoms that are dissolved in all the cosmic creatures that move together, so the universe is found; if they are separated from each other, it leads 
the universe to nothingness. The time is the movement of these atoms, and the place is where these separated atoms are found.

There is no doubt that Ibn 'Arabī has benefited from this theory, but wanted to go beyond those problems that were occurring in the dilemma of "creation" as the existence and nothingness, and oldness and newness.

This perception of the fact of the facts with its central position as the existential mediator between God and the world on the one hand, and as cognitive mediator between God and man, on the other hand, makes Ibn 'Arabī able to take the apparent meaning of the verses of divine qualities, considering that these qualities are the facts that are in the divine, as well as these are also the facts that are in the human self. The difference between the two selves, not between the two qualities is the basis of the discrimination. Therefore, he answers to the Interpreters - especially Mu'tazila denying their interpretations on the basis that they ignored the metaphor to explain by the objects, and fell in the simile to explain by the meanings, especially in the verse of the equator, when they interpreted the equator as it is to take over. [20]

\section{Theory of the actor cause and material cause to the philosophers}

As we assumed the concept of divinity to Ibn 'Arabī could be equated with the concept of the actor cause to the philosophers, the concept of the fact of the facts or cosmic symptoms can be equal to the concept of the material cause, as Ibn 'Arabī himself applies to the fact of the facts; he uses some names such as the total material or the first material or the genus of species. We mention here the four causes and their relevance to the four cosmic symptoms to Ibn 'Arabī, to see the impact of these causes in the thought of Ibn 'Arabī in this regard.

"The theory of the ideals is a centre of Platonic doctrine. It links the things perceived and are reasonable. It explains the science and the world. It necessitates an existence of the simple spiritual self understands the abstract ideals and attributes the existence of self to the past of the current life. It ensures that they have the two-sided immortality does not expire as the simple does not slim and that which has its existence by itself without the body can be found by itself after going out of the body." [21] 
"Plato holds that ideals and essences are inherent in the self. The self before its entrance in the body was living amongst these ideals being related to them, but when it committed a sin in the world of ideals, it entered the body. Then the body made it forget the ideals because of the density of its material." [22]

He believes that there is another world behind this world, which is the world of the ideals. Plato separated the ideals from the things and made an independent world for them, and made an independent existence for each ideal. He said that the ideals are the essences of things and their spirit.

Aristotle said, we can not imagine the existence of a thing without its essence, and then the essence of the thing must be in the thing, not beyond that thing. He decided that the sensuous thing is the real existent. He said that all the creatures in the universe, whether natural or human-made, have four causes. These include the physical cause, imaginational cause, actor or movable cause, and teleological cause, which can further be grouped into two. The first: the cytoplasm, which is the first material, is not fixed originally. The second: the picture that the principle that sets the cytoplasm and gives it a special essence and particular form, so the picture is the example to Plato, but this image is located in the sensory thing, not in the world of ideals, and not separated from the thing. The object is composed of the unity of these two principles. Aristotle said that the difference amongst the creatures and objects is due to the picture, not to the cytoplasm. He said that the movement is the cause of the different images, because of the motion there is a succession of the night and day and the seasons. On this basis, Aristotle considered that everything among the creatures consists of cytoplasm and image. The cytoplasm, which consists of raw materials that make up different things, is the primordial material, which makes up the unlimited objects of the universe including their qualities and quantities, and it is capable of taking different recipes. If it has taken a picture or some recipes become a particular substance; for example, if the cytoplasm took some recipes or essence or image of gold, it became gold, and if it took a picture of wood the result was wood. Then the first material is valid to be any substance, so it has its existence, which is capable of being formed and shaped in any form or shape, and if it has taken a recipe (picture) of a material, it 
exists by force, but it cannot exist actually until it takes a recipe (picture) of a material. The first material in itself has no picture, no appearance, and has no prescription or definition, which makes it a noun of an adjective that makes us know and realize that it is the picture. Thus, Aristotle attributed different objects and materials and their situations to their different pictures and not to their different materials in their sizes and their quantities, as it was believed by the natural philosophers.

\section{Theory of Emanation to Neo-Platonism}

The founder of Neo-Platonism was Numenius, who lived in Syria in the second century AD. His texts were taught in the school of Plotinus himself. Plotinus was not the real founder of new Platonism. Plotinus was accused by his contemporaries that he had stolen the views of Numenius. However, Plotinus is placed in the history of European thought at one level with Plato and Aristotle.

It is known that Plotinus had joined the Roman army during the war against Persia. Plotinus wanted to know the Persian and Indian thought, but after the defeat of the Roman army in Iraq Plotinus took refuge to Antioch, where Numenius was teaching in the Syrian Cultural Center. So the first foundation of Neo-Platonism was in the east, in Antioch, not in the West (Alexandria-Rome). Numenius was one of the most famous Syrian Platonists that were affected by Neopythagoreans on the one hand and by the Eastern religions on the other hand.

The doctrine of Neo-Platonism by Numenius was based on three principles of the theory of flux (or Emanations): The first mind (or good in itself or the supreme God) creator of the second minds. Then the second mind in the second place: (The son or the manufacturer of the world or the manufacturer god) who created the world from the material, and finally the world with all its articles in the third place. Numenius had believed that the first mind (God) was not fit to create the world Himself. Therefore, this task was leaved to His successor: (the second mind). Neo-Platonism had two main versions: Eastern version: (Levantine -Persian) and Western version: (Alexandrian- Christian). What distinguishes the two versions of "Neo-Platonism" is how their respective ideas were hired in the theory of flux. As the Eastern Levantine version was 
representing the theory of ten minds and the Western version was representing three: (Christian triangulation).

\section{Theory of Cosmic Symptoms in Hindu Mythology}

Like other people, Hindus also have mythology. Hindu mythology has what is stated in the legends of other Aryan nations, like Greeks, Romans and Germans in their ancient times. Not only the mythology was similar amongst many Aryan peoples, but the names of the gods and their functions also were similar. It is not unlikely that Ibn 'Arabī has a look at what is stated in the theories of Hindus about the creation of the universe. It seems that when Ibn 'Arabī wanted to weave his scientific fabric for the cosmic symptoms, he had also gleaned from several sources, as well as the Hindu mythology about the creation of the universe. For the evidence we mention here some poetic stanzas that are written in the poetry of Sir Williams about (Nārāyin), which is as follows:

- "Hey, you're the spirit of life, which has seized the place on all its sides and extended the time, that has no end."

- "You ordered the noise to take for a beautiful system beyond the limits of the High imagination."

- "You had your existence before the existence of sky; then you took the possession on the throne",

- "It was before the existence of celestial bodies took place above us and beneath us,

- And before the earth suspended itself in the astronomer air.

- It was because of your hidden love.

- And the things that did not exist sprang up to existence." (It means: that the things had their existence in the nothingness before their appearance in the gallery of the existence.)

- Brahma (the God) observed His mind (knowledge) before the spirit was emitted and the shapes were presented.

- When the mortal eyes saw the things in the bright mirrors (i.e., an unlimited divine self appeared to look at the things by the limited mortal eyes).

- A most beautiful form sprang up to existence with a high gloss,"

- By this luxury was the Creation of the world. 
- And when God wanted to create an unlimited number of the worlds appeared from the oneness to the multitude (the multiplicity)." [24]

\section{Conclusion}

These stanzas are taken from Indian mythology. Some parts of them indicate that it is not unlikely that Ibn 'Arabi was benefited in his idea of "divine science", "the existence of objects fixed into the nothingness" and "the emergence of a single (God Almighty) from the oneness to the multitude, when He wanted to create an unlimited number of worlds". This statement is the main point in the theory of Ibn 'Arabī. The philosophical sources of the mediator world between God and the human world in his theory have their roots and origins that stretch from Plato to Plotinus, then to Illuminists in Islamic philosophy. No doubt there are many similarities between Ibn 'Arabī and the scholars need to compare and discuss.

Furthermore, we believe that some elements in his scientific fabric are taken from Plotinus who tried to show the special existential relationship between the human soul in its higher level and the one that is the absolute essence for every existent and has succeeded in reconciling and combining the theory of Greek pantheism and Indian pantheism. Plotinus begins his philosophy starting with his reflections about the existence. He believes that the existence is the foremost: It comes out from the one for each pattern of the instantiations, that are the ranks of the one cosmic existence or are the manifestations of the same of one object per aggregate, as the one manifests in the first place, i.e., the existence itself in its presence and its being unlimited exactly. The one is not a mind or a spirit, but it is good, then the existence thought about itself. So it became two without a partition into two parts: the existence and prudence. Then the action of the prudence embodied, which is only a division can be considerable to the soul and theme. As the sane and sensible embodied in the first iceberg or the first configure, which is the mind or total comprehensive mind. Then the action of this total comprehensive self in the perceived world emerged from the mind, as each partial soul branched out from the mind until it reached this emanation or came out to the material world, which is the last level of a series of the stages of existence. [25] 
The thoughts of Ibn 'Arabī could be compared with the thoughts of Plotinus by many similarities between them, but there are also some differences between Plotinus the mystic and Ibn 'Arabī the Sufi. The mysticism to Plotinus is a mental mysticism and the mediators, that mediate between God and the man, are the mental mediators as well, while the mysticism to Ibn 'Arabì does not depend on the mind completely and the mediators are also not mental mediators, as they are not based on the theory of (Emanation) or the overflowing of all organisms gradually through the first one. So the universe that does come up from the one to Plotinus, that one is equal to the divinity, which is a level of the absolute utopian world, named by Ibn 'Arabi the isthmus of the isthmuses, which is also in its turn a mediator between the divine and world. The overflowing of the universe from the divinity and cosmic symptoms is not by the overflowing or through the emanation to Ibn 'Arabī, but a series of transfigurations. We should not forget that the transfiguration to Ibn 'Arabī is an alternative word for the overflowing or emanation to Plotinus.

The theory of emergence of the existence to Plotinus is similar to Hindu doctrine about the beginning of creation, as Hindus believe that God (Parajapati) is the creator and at the same time He is the creation (or sane and sensibility to Plotinus) because He was one at the first, He loved the multitude and wished for the reproduction. He became in many parts scattered all over the world. So, the whole world became existed from these parts. Hence the theory of pantheism begins, because the unlimited existent or the total essence, which was only the one, may feel a desire to the multiplicity, creating the light. The light felt similar desire, creating the water. The water felt a similar desire, creating the earth, as it is found in the essence of The Vedas. [26] This is a fact that no body can refuse that this reality of Hindu pantheism is found in the thought of both Plotinus and Ibn 'Arabī.

We also find in the thought of Ibn 'Arabī some of the elements inherent in the doctrine of Trinity to the Christians. Augustine tried to prove the theory of uniformity in the triangulation by a few examples, including "the scientist, the knowledge or which is known and the means of the science; though these three separate things are different among themselves, but they have become one, as they are 
represented and combined in the brain, the scientist has his existence, knowledge has its existence and machine of the science has its existence, meaning that the brain holds all the three recipes: The scientist, the knowledge and the machine of knowledge. Each of them carries one of these three qualities that can be described as the brain, but on this basis, we cannot say that the brain is called the three things individually. From this perspective, one can imagine God as three Persons, and each of these three Persons is God; but it does not mean that God is three, He is only one God. [27]

The philosophical terms used by Ibn 'Arabī in the statement of the first existential rank, indicate that these terms are similar to the concept of the causes of the first material and that the things came from them to the philosophers.

It must be noted that the multiplicity of the term to Ibn 'Arabī is to signify one thing, which is due to his centrist nature or middleground thinking more than the uncertainty or confusion, which he was accused of by some researchers. This comes up because he seeks monotheism, then includes all the terms available to expresses the one fact, while each term has its different aspects in a unified scientific format.

Ibn 'Arabì from one side does not describe these facts by the existence or nonexistence but puts them in the middle rank between the ubiquity and the limited existence. On the other hand, when he talks about the ranks of creatures as the spirituality and the embodiment - the capabilities of their bias from their nothingnessput these facts in fourth place. These are the creatures that do not accept bias alone, but they accept it by the extension, as they do not stand by themselves, but they are resolved in the others, i.e., they are symptoms, like -the whiteness and blackness etc. including the assets of the attributions that happen to these creatures of three types. The first, the ubiquity that cannot be realized, that is God. The second is out of the material, like spiritual minds that accept the figure and shape, namely the angels and jinn. The third, the existent that accepts the bias and place, like the celestial objects, bodies and the individual essences (to Mu tazila and Asha ira from the scholastic theologians) and other symptoms, like: where, how, the time, number, quality, quantity, amount and addition, situation and to do and to get excited. Every one of these creatures is divided in itself to many types. 
The idea of the isthmus to Ibn 'Arabì in the opinion of some researchers like 'Abu al- 'Elā 'Afifi is taken from the concept of the word: Logos. As 'Abu al-'Elā 'Afifi considers that the concept of the isthmus -uniting with the concept of the word: Logos- is influenced by the idea (Logos) of Philon from Alexandria. 'Afifi believes that the impact of this concept is prominent clearly in the similarities between the terminologies used by both of them.

It is true that Ibn 'Arabī has gleaned from each party, but he differentiates sharply between the divine and the world. However, this distinction or bilateral becomes narrow to the point of absence. He differentiates by the existence of this total mediator, which unites all the mediators as the whole, through which God reflected in the pictures of essences of the possible creators. These are only the fictional mediators, considering that each of them corresponds to God as the divine self alone and in the same way corresponds to the creation (Creatures). Ibn 'Arabī says: "What a broader presence of the imagination, which shows the presence of the impossible as its existence, as the existing absolute God does not accept the image, has appeared in the image of this presence, by this way which was impossible as its existence accepted to exist in this presence. [28]

The existential rank of the fact of the facts itself is the existential rank of the divinity to Ibn 'Arabī. It is also like the proportions and additions that do not have a real existence, and they cannot be described with the existence or nonexistence, as it can be called by both of them at the same time. If Ibn 'Arabi often unites the fact of the facts with the ten arguments of the philosophers [29]. At some other times, he unites it with the divinity [30], but it is important that he puts it, like divinity, in the middle rank between the ubiquity and bounded and added, and describes it with all the qualities that can be applied to all the rank of divinity. If the fact of the facts represents the content of divine science - which necessarily involves the knowledge of the self - it is easy for the fact of the facts to be united with the divinity in its existential rank. Recipe of science - from the other side - is one of the facts of divinity. The fact of the facts - from this angle - is one of the divine realities. If the science is the scientist and that is known, we can recognize that the fact of the facts "represents the inside of the divinity and the divinity represents the outside of the fact of the facts." [31] 
We think that the fact of the facts, as being united with the divinity, as the existential and cognitive existence, represents a mediator between God and the world from one side and between God and the man on the other. The existence of the fact of the facts to Ibn 'Arabī is a reasonable mental existence, not a real sensuous existence. Ibn 'Arabī casts the same existence on the fantasy or isthmus. According to Ibn 'Arabī, this reasonable existential rank is also counted one of the existential ranks. It is an important rank, not less than a sensuous existence, which gives these mediators a measure of the significance and independence that stands as an obstacle against the pantheism in the contemporary philosophical sense. 


\section{References}

[1] Reynold Alleyne Nicholson: (Preface of the book): The mystic of Islam, translated by 'Afifi. 'Abu al- Ela. (1969). Cairo: Press of the authoring, translating and publishing committee.

[2] Muthanna. Hasan. (1965). Iqbal and al-Sheikh al- 'Akbar. India: House of the classifying and authoring. Mubarkpur, Azam Garh, (U. P.). p. 7-8

[3] Ibn 'Arabī. Muhyiddīn. (1946). Fuṣūṣ al-Hikam, Cairo: p: 55. See also: Al-Mișri, Husain Mujib. (1981). Iqbal among the Islamic Reformers. Cairo: Anglo Egyptian Library. p. 276

[4] Ibn 'Arabī. Muhyiddīn. (No date). Mecca Conquests. Beirut: Dār Sādir, part: 4, pp. 208-209, as well as part: 2, pp. 203-379 and also part: 3, p: 358

[5] Ibn 'Arabī. Muḥyiddīn. (No date). Creation of Circles, Leiden, 1339 , p. $16-19$

[6] Ibid, pp. 17-19

[7] Ibid, p. 31

[8] Ibid, p. 241 and also Mecca Conquests, part: 1, p. 119

[9] Ibn 'Arabī. Muhyiddīn. (1946). Cloves Rule, the introduction by Abu Ela Afifi. Beirut: Arab Book House. P. 30

[10] Ibn 'Arabī. Muhyiddīn ........ Creation of Circles. pp. 20-21 See also: Mecca Conquests, part: 2, p. 454

[11] Ibn 'Arabī. Muhyyiddīn........... Mecca Conquests, Beirut: Dār Șādir. Part: 3, p. 79

[12] Ibid, part: 1, p. 77 
[13] Ibn 'Arabī. Muhyiddīn. ........ Creation of circles, Leiden, 1339 , p. $24-26$

[14] 'Afifi, 'Abu al- Ela. (1933). Mystical philosophy of Ibn 'Arabī. Cairo: Journal issued by Faculty of Arts, Cairo University, p. 34

[15] Ibn 'Arabī. Muhyyiddīn. Cloves Rule, p. 55

[16] Al-Khwarizmi. (1968). Keys of the sciences. Leiden: p. 17

[17] Pines (D-Q). (1946). Doctrine of the corn to Muslims. Egypt: Translated by Muḥammad 'Abdul Hādi 'Abu Riḍā. First edition, p. 4-5

[18] Alusi. (1967). Problem of Creation. Baghdad: p. 71

[19] 'Izz al-Din 'Abdul Sattar. (1980). Mind and Freedom. Beirut: Arab Institute for Research and Publication, pp. 297-298

[20] Ibn 'Arabī. Muhyiddīn. (No date). Mecca Conquests. Beirut: Dār Șādir, part: 1, p. 681

[21] Madkūr, Ibrāhīm Bayyūmī. (1953). Lessons in the history of philosophy. Cairo: National Ministry of Education, p. 19

[22] Șalah, 'Abdul Gawād. (No date). Origins of Psychology. Cairo: Modern Printing House, p. 191

[23] It is translated from an article in Arabic entitled: "Hindu mythology about the universe and creation". India: Journal: The culture of India, September 1956, pp. 39, 40-41

[24] Al-Jaberi, Muhammad Abid. (1986). We and Heritage. Morocco: Arab Cultural Center. Casablanca. Fifth Edition, pp. 133136

[25] Salahuddin Mohd. Shamsuddin. (2015). God in the faith of Muslims, Christians and Jews. Malaysia: Press of University Malaya. p. 18 
[26] Ibid, p. 19

[27] Augustine, Part: 2, p. 92

[28] Ibn 'Arabī. Muhyiddīn. (No date). Mecca Conquests. Beirut: Dār Șādir, part 2, p. 312

[29] Nașr Hāmid 'Abu Zayd (1996). Philosophy of interpretation. Beirut: Arab Cultural Center, pp. 67-74

[30] Ibn 'Arabī. Muhyiddīn. (No date). Mecca Conquests. Beirut: Dār Șādir, part 1, p. 77-119

[31] 'Afifi, 'Abu al- 'Ela. (1933). Mystical philosophy of Ibn 'Arabī. Cairo: The Journal issued by Faculty of Arts, Cairo University, p. 68 